\title{
Faktor yang Mempengaruhi Kelengkapan Penulisan Dokumentasi \\ Keperawatan
}

\section{Lili Evalina}

\author{
lili.evalina@gmail.com
}

\section{Latar Belakang}

Kelengkapan dokumentasi menjadi salah satu hal yang krusial dalam sebuah rumah sakit maupun dalam karir seorang perawat. Hal ini dikarenakan pentingnya kelengkapan dokumentasi keperawatan yang pada dasarnya menjadi indikator utama dari penilaian baik dari rumah sakit maupun perawat itu sendiri. Namun meski pentingnya kelengkapan dokumentasi keperawatan ini sudah menjadi salah satu hal dasar yang pasti diketahui oleh seorang perawat, tetapi tidak menutup kemungkinan untuk terjadinya ketidaklengkapan dokumentasi keperawatan ini sendiri yang dikarenakan oleh beberapa hal. Menurut Teytelman (2002), apabila hal ini terjadi maka akan berdampak kepada beberapa hal lainnya seperti kerugian bagi klien karena informasi penting terkait perawatan dan kondisi kesehatannya yang sudah diperiksakan pada rumah sakit tersebut terabaikan begitu saya.

Juga dijelaskan oleh Fischbach (1991) bahwa kelengkapan dokumentasi keperawtan ini menjadi penting karena berhubungan dengan hal - hal krusial dalam dunia keperawatan itu sendiri seperti untuk mengetahui, memantau, dan menilai suatu pelayanan asuhan keperawatan yang dilakukan dalam sebuah rumah sakit yang bersangkutan. Hal ini menjadi berhubungan dengan apa yang sudah disampaikan oleh Teytelman diatas, karena apabila dokumentasi yang dimiliki oleh rumah sakit dan perawat tidak lengkap, maka berbagi informasi penting yang dapat digunakan untuk keperluan keperawatan, rumah sakit, dan pasien pada akhirnya akan hilang. Kelengkapan dokumentasi ini juga menjadi salah satu bukti dari pertanggunggugatan dari setiap tim perawat menurut Potter \& Perry (2005).

Juga dikatakan oleh Gillies (2000) dan Carpenito (1999) bahwa kelengkapan dokumentasi ini menjadi penting juga karena menjadi salah satu bukti dari tindakan yang dilakukan oleh perawat dalam menjalankan tugas keperawatannya mengenai sesuai tidaknya tindakan yang diambil oleh perawat tersebut. Juga dokumentasi ini menjadi salah satu sarana 
komunikasi antara perawat dengan pihak rumah sakit untuk menyampaikan berbagai informasi yang diperlukan oleh kedua belah pihyak. Dokumentasi yang awalnya dibuat oleh perawat ini pada akhirnya menjadi sangat penting untuk disusun secara lengkap agar tidak terjadi bias informasi dari perawat kepada pihak rumah sakit sehingga pihak rumah sakit pada akhirnya juga dapat mengolah informasi dalam dokumen dengan baik dan tepat.

Berbagai penjelasan dan penjabaran mengenai pentingnya kelengkapan dokumentasi keperawatan ini dapat menjadi salah satu alasan pentingnya memahami apa saja faktor yang dapat mempengaruhi kelengkapan dokumentasi ini sendiri. Hal ini perlu untuk dipahami agar mampu menghindari atau mengatasi berbagai faktor yang dapat mempengaruhi kelengkapan dokumentasi keperawatan ini sendiri. Faktor yang dimaksud disini pun tidak sedikit karena berasal dari berbagai aspek dalam dunia keperawatan yang berhubungan dengan perawat itu sendiri. Maka dari itu kelengkapan dokumentasi keperawatan dapat dilakukan dengan baik dan maksimal apabila seorang perawat juga telah mengetahui dan memahami apa saja faktor - faktor yang dapat mempengaruhi kelengkapan dokumentasi keperawatan ini.

\section{Metode}

Metode yang digunakan dalam penulisan jurnal ini adalah metode kualitatif dengan pendekatan kajian pustaka. Dalam penelitian ini data yang digunakan berasal dari sumber sumber dengan topik yang bersangkutan seperti dari jurnal keperawatan, buku, thesis, skripsi, maupun dari website dan blog dari internet. Dalam arti lain dengan menggunakan kajian pustaka, maka apa yang akan ditulis dalam jurnal ini merupakan hasil dari penelitian terdahulu yang membahas masalah yang sama. Dengan menggunakan metode kualitatif ini juga data yang disampaikan akan berbentuk penulisan dan penjabaran dan tidak dikemas secara statistik.

\section{Hasil}

Berdasarkan apa yang sudah dipaparkan pada bagian pendahuluan, maka dapat dikatakan meskipun kelengkapan dokumentasi keperawatan merupakan salah satu hal yang penting dalam dunia keperawatan, tetapi masih terdapat beberapa faktor lainnya yang dapat mempengaruhi kelengkapan dokumentasi keperawatan ini. Berbagai aspek dalam keperawatan menjadi suatu faktor - faktor yang mempengaruhi kelengkapan dokumentasi keperawatan ini. Salah satu faktor 
yang mempengaruhi kelengkapan dokumentasi keperawatan ini adalah kinerja perawat yang bersangkutan ini sendiri dalam melakukan pendokumentasian.

Selain kinerja perawat, faktor psikologis juga dapat mempengaruhi kelengkapan dokumentasi keperawatan ( Gibson, et all, 1996). Faktor organisasi juga dapat mempengaruhi kelengkapan dokumentasi keperawatan, misalnya pada saat seorang perawat merasa keberatan dan terpaksa pada saat melakukan dokumentasi keperawatan yang biasanya dikarenakan kurangnya waktu yang diberikan kepada perawat yang bersangkutan untuk menyelesaikan tugas dokumentasinya. Hal ini kemudian mempengaruhi kelengkapan dokumen itu sendiri karena apa yang dikerjakan oleh perawat yang bersangkutan dalam menyelesaikan dokumentasi tersebut tidak maksimal sehingga hasil dari dokumentasi tersebut pun tidak lengkap.

Faktor selanjutnya yang dapat mempengaruhi kelengkapan dokumentasi keperawatan adalah tingkat pendidikan perawat yang bersangkutan, beban kerja yang diberikan, usia, lingkungan, dan karakteristik perawat. Dari apa yang disampaikan disini dapat terlihat bahwa faktor yang mempengaruhi kelengkapan dokumentasi keperawatan ini tidak berasal dari satu aspek saja, melainkan dari berbagai aspek dalam keperawatan mulai dari aspek - aspek eksternal yang mana dipengaruhi oleh lingkungan dan hal lainnya diluar diri perawat itu sendiri seperti organisasi dan beban kerja. Selain itu juga terdapat aspek - aspek internal yang juga dalam hal ini menjadi faktor yang mempengaruhi kelengkapan dokumentasi keperawatan, seperti halnya usia perawat, karakteristik perawat, dan tingkat pendidikan perawat yang dapat digabungkan dalam faktor psikologisnya.

\section{PEMBAHASAN}

Berbagai faktor yang mempengaruhi kelengkapan dokumentasi keperawatan ini berasal dari berbagai aspek sehingga menjadi menarik untuk dibahas lebih dalam lagi. Salah satu contohnya adalah faktor tingkat pendidikan perawat yang pada akhirnya akan mempengaruhi kelengkapan dokumentasi keperawatan. Perawat yang memiliki pendidikan kurang memenuhi kriteria sebagai seorang perawat biasanya akan kesulitan untuk membuat sebuah dokumentasi keperawatan yang lengkap, yang mana pada akhirnya akan berpengaruh pada kelengkapan dokumentasi keperawatan ini sendiri. Hal ini dikarenakan seorang perawat yang kurang pendidikannya tidak memiliki ilmu yang cukup mengenai bagaimana menghasilkan atau 
menyusun sebuah dokumentasi keperawatan yang lengkap, atau juga menganggap bahwa dokumentasi keperawatan yang mereka susun sudah lengkap dimana pada kenyataannya dokumentasi tersebut belum mencapai kata lengkap karena masih ada beberapa bagian yang terlewat.

Hal ini sejalan dengan apa yang disampaikan oleh Ridley (2008), dimana ia mengatakan bahwa pendidikan merupakan faktor penting yang akan mempengaruhi kinerja seseorang, yang dalam hal inis ecara spesifik akan ditujukan kepada seorang perawat. Juga dikatakan bahwa tingkat pendidikan akan berbanding lurus dengan kinerja seseorang, dimana semakinh tinggi tingkat pendidikan seseorang maka semakin tinggi pula pengathuan dan ketrampilan orang tersebut yang meliputi pemikiran kritis, wawasan luas, harapan yang tinggi, serta prestasi kerja yang baik. Maka dari itu pendidikan menjadi faktor yang mempengaruhi kelengkapan dokumentasi keperawatan karena semakin tinggi tingkat pendidikannya maka semakin baik kinerja perawat tersebut dalam menyusun dokumentasi keperawatan yang pada akhirnya akan membuat dokumentasi keperawatan tersebut menjadi sebuah dokumentasi yang lengkap.

Juga dikatakan bahwa usia menjadi salah satu faktor yang dapat juga mempengaruhi kelengkapan dokumentasi keperwatan ini. Sebuah penelitian mengatakan bahwa pada dasarnya perawat dengan usia diatas 30 tahun sebagian besar menjadi perawat yang paling optimal dalam melakukan dokumentasi keperawat sehingga dokumentasi keperawatan yang dibuat atau disusun oleh perawat dalam rentang usia tersebut umumnya merupakan dokumentasi keperawatan yang lengkap. Hal ini sejalan dengan pernyataan yang disampaikan oleh Potter dan Perry (2010) dimana mereka mengatakan bahwa individu dalam rentang usia 30 hingga 60 tahun akan memasuki fase masa tenang atau fase keberhasilan dimana dalam rentang usia ini pula individu termasuk dalam kategori dewasa menengah yang mana produktivitas seseorang dalam rentang usia tersebut sangat tinggi sehingga berpengaruh pada hasil akhir dari pekerjaan mereka, yang mana dalam hal ini adalah kelengkapan dokumentasi keperawatan.

Masa kerja juga menjadi salah satu hal yang mempengaruhi kelengkapan dokumentasi keperawatan, dimana dikatakan bahwa masa kerja seprang perawat yang lebih tinggi akan berbanding lurus dengan pengalaman perawat tersebut dimana dalam hal ini termasuk pada keterampian klinisnya (Swansburg, 1999). Hal ini juga didukung dengan hasil penelitian Lusianah (2008) yang membenarkan hubungan antara lama masa kerja seorang perawat dengan 
kualitas dokumentasi keperawatan yang disusunnya. Namun ada beberapa kontra terhadap hal ini dimana dikatakan bahwa pada dasarnya tidak ada suatu kaitan yang pasti mengenai hubungan antara lama masa kerja seorang perawat dengan kelengkapan dokumentasi keperawatan yang mereka susun karena hal ini tidak dapat hanya dilihat dari tingkat senioritas, namun dalam hal ini juga dikatakan bahwa salah satu hal yang mungkin membuat kedua hal ini menjadi saling berhubungan adalah fakta dimana semakin lama seseorang bekerja dalam suatu bidang makan akans emakin kecil kemungkinan orang tersebut akan berpindak ke pekerjaan lain.

Masih mengenai lama masa kerja seseorang, seorang perawat dengan masa kerja yang lebih lama tentu akan memiliki pengalaman yang jauh lebih banyak meliputi pengetahuan dan keterampilan dalam pekerjaannya sebagai seorang perawat dibandingan dengan perawat dengan masa kerja lebih singkat. Dikatakan juga bahwa setiap penambahan masa kerja seorang perawat selama satu tahun, maka kualitas dokuemntasi keperawatan tersebut juga akan meningkat sebesar 0.91 berdasarkan hasil kontrol variabel mjotivasi kebutuhan kekuasaan, kebutuhan afiliasi, kebutuhan berprestasi, supervisi, pendidikan pengetahuan dan pelatihan (Lusianah, 2008).

Maka dari itu dapat dikatakan bahwa seorang perawat pada dasarnya memerlukan waktu yang lebih agar dapat menyusun sebuah dokumentasi keperawatan yang lengkap karena berdasarkan hasil penelitian yang sudah dijelaskan diatas, kualitas dokumentasi keperawatan juga akan bertambah secara bertahap seiring dengan masa kerja perawat tersebut. Meski demikian hal ini harus diimbangi dengan tingkat tanggung jawab perawat yang bersangkutan di tempat kerja agar dapat berkembang dengan maksimal selama berada dalam proses menjadi seorang perawat yang berdedikasi. Selain itu juga diperlukan pelatihan yang terfokus pada perawat - perawat dengan masa kerja yang masih dapat dikatakan singkat seperti berupa pelatihan yang terkontrol menegai variabel beban kerja.

Hal ini juga disampaikan oleh Lusianah (2008) yang mengatakan bahwa pelatihan yang diberikan kepada perawat akan mempengaruhi kualitas dokumentasi keperawatan, dimana dikatakan setiap diberikannya pelatihan kepada perawat yang membutuhkan, maka akan terjadi peningkatan sebesar 1,60 kali dalam kualitas dokumentasi keperawatannya dibandingkan dengan perawat yang tidak pernah mendapatkan pelatihan sama sekali selama masa kerjanya. Hal ini didukung dengan pendapat dari Jefferies, Johnson, Nicholls, dan Lad (2012) dimana mereka mengatakan bahwa fokus dari peningkayan pengetahuan melalui penelitian ini adalah 
meningkatkan dokumentasi keperawatan yang dilakukan oleh perawat. Maka dari itu dapat dikatakan bahwa lama masa kerja seorang perawat tidak dapat meningkatkan kualitas dokumentasi perawat tersebut apabila tidak diimbangi dengan pelatihan yang diberikan pada perawat yang bersangkutan.

Beban kerja perawat yang diakbatkan oleh pemberlakuan sistem shift pada perawat. Dengan adanya sistem shift ini, maka para perawat akan mempunya beban kerja yang lebih tinggi dimana pada akhirnya berpengaruh pada kualitas dokuemntasi keperawatannya. Berdasarkan hasil penelitian, perawat dengan beban kerja yang tinggi tidak mampu menyelesaikan pendokumentasian secara lengkap dan hanya sebanyak $16,7 \%$ perawat dengan beban kerja tinggi yang mampu menyelesaikan dokumentasi keperawatan secara lengkap. Hal ini dikarenakan tingginya beban kerja perawat akan mempengaruhi produktivitas perawat yang bersangkutan sehingga pada akhirnya akan berpengaruh baik secara langsung maupun tidak langsung kepada kualitas dokumentasi keperawatannya.

\section{Penutup}

Setelah pemaparan mengenai berbagai faktor yang dapat mempengaruhi kelengkapan dokumentasi keperawatan ini, maka dapat dikatakan bahwa faktor - faktor tersebut datang dari berbagai aspek dalam dunia keperawatan sehingga penting bagi seorang perawat untuk dapat mengetahui dan memahami tentang berbagai faktor ini agar dapat meminimalisir ketidaklengkapan dokumentasi keperawatan. Hal ini juga seperti yang sudah disampaikan bahwa tidak lengkapnya dokumentasi keperawatan akan berdampak bagi setiap pihak mulai dari pihak rumah sakit, perawat, hingga pasien. Maka dari itu mengetahui dan memahami faktor - faktor yang dapat mempengaruhi kelengkapan dokumentasi keperawatan ini menjadi salah satu langkah yang dapat dilakukan untuk meminimalisir terjadinya hal - hal negatif yang berkaitan dengan kelengkapan dokumentasi keperawatan ini. 


\section{DAFTAR PUSTAKA}

Andri, F., Indra, R., \& Susmarini, D. (2015). MANUSKRIP ANALISIS FAKTOR - FAKTOR YANG MEMPENGARUHI PERAWAT DALAM MEMENUHI KELENGKAPAN DOKUMENTASI KEPERAWATAN DI IGD RUMAH SAKIT WILAYAH PONTIANAK KALIMANTAN BARAT. Jurnal Medika Respati Vol X Nomor 4 , 49-57.

Fatmawati, D., Ismawati, \& Suriawanto, N. (2019). Faktor-Faktor Yang Mempengaruhi Dokumentasi Terhadap Kelengkapan Asuhan Keperawatan Oleh Perawat Pelaksana di Ruangan IGD RSU Anutapura Palu. Journal Of Midwifery And Nursing Volume 1 No.2, 35-36.

Kimalaha, N., Mahfud, \& Anggraini, A. N. (2018). Pengetahuan dan Beban Kerja Perawat Berhubungan Dengan Kelengkapan Pendokumentasian Asuhan Keperawatan di Bangsal Penyakit Dalam dan Bedah. Indonesian Journal of Hospital Administration Vol 1, No 2 , 79-81.

Noviari, E. A., \& Susanti, D. D. (2015). FAKTOR-FAKTOR YANG MEMPENGARUHI KELENGKAPAN DOKUMENTASI ASUHAN KEPERAWATAN DI RUANG BEDAH RSUD dr. SOEKARDJO KOTA TASIKMALAYA. Buletin Media Informasi Edisi 1 , 26-34.

Noorkasiani, Gustina, \& Maryam, R.S. (2015). FAKTOR-FAKTOR YANG BERHUBUNGAN DENGAN KELENGKAPAN DOKUMENTASI KEPERAWATAN. Jurnal Keperawatan Indonesia Vol 18 No 1, 5-7

Salim, A. (2020). FAKTOR-FAKTOR YANG BERHUBUNGAN DENGAN KELENGKAPAN DOKUMENTASI PENGKAJIAN RAWAT JALAN DIRUMAH SAKIT AWAL BROS BATAM TAHUN 2016. Journal of Hospital Administration and Management Vol 1, No. 1, 1-7.

Simamora, R. (2009). Dokumentasi Proses Keperawatan.

Simamora, R. H., Purba, J. M., Bukit, E. K., \&Nurbaiti, N. (2019). Penguatan Peran Perawat Dalam Pelaksanaan Asuhan Keperawatan Melalui Pelatihan Layanan Prima. JPPM (Jurnal Pengabdian Dan Pemberdayaan Masyarakat), 3(1), 25-31.

Siswanto, H., Hariyati, T. S., \& Sukihananto. (2013). FAKTOR - FAKTOR YANG BERHUBUNGAN DENGAN KELENGKAPAN PENDOKUMENTASIAN ASUHAN KEPERAWATAN. Jurnal Keperawatan Indonesia, Volume 16 No.2 , 78-83.

Supratti, \& Ashiandy. (2016). PENDOKUMENTASIAN STANDAR ASUHAN KEPERAWATAN DI RUMAH SAKIT UMUM DAERAH MAMUJU, INDONESIA. Jurnal Kesehatan MANARANG Vol 2 No 1, 47-48

Syaiful, Y., \& Mujafafa, E. (2012). BEBAN KERJA DAN MOTIVASI KERJA PERAWAT DENGAN KELENGKAPAN DOKUMENTASI KEPERAWATAN. Journals of Ners Community Vol 3 No 1, 58-60. 
Ulum, M.M, \& Wulandari, R.D. (2013). FAKTOR YANG MEMPENGARUHI KEPATUHAN PENDOKUMENTASIAN ASUHAN KEPERAWATAN BERDASARKAN TEORI KEPATUHAN MILGRAM. Jurnal Administrasi Kesehatan Indonesia Vol 1 No 3, 252-253 